\title{
The effectiveness of autobiographical memory specificity training on depression and co-rumination in depressed students
}

\author{
Mehrnoosh Poursaeid Esfahani ${ }^{1}$, Mahgol Tavakoli ${ }^{2 *}$ (iD), Hamid Taher Neshatdost ${ }^{3}$ \\ 1. MA in Clinical Psychology, Department of Psychology, Faculty of Educational Sciences and Psychology, University of Isfahan, Isfahan, Iran \\ 2. Assistant Professor of Psychology, Department of Psychology, Faculty of Educational Sciences and Psychology, University of Isfahan, \\ Isfahan, Iran \\ 3. Professor of Psychology, Department of Psychology, Faculty of Educational Sciences and Psychology, University of Isfahan, Isfahan, Iran
}

Recieved: 6 Apr. 2019

Revised: 23 Jume 2019

Accepted: 23 Jul. 2019

Keywords

Depression

Memory specificity training

Autobiographical memory

Co-rumination

\section{Corresponding author}

Mahgol Tavakoli, Assistant Professor of Psychology, Department of Psychology, Faculty of Educational Sciences and Psychology, University of Isfahan, Isfahan, Iran

Email: M.tavakoli@edu.ui.ac.ir

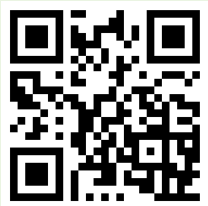

\section{Abstract}

Introduction: Reduced specificity of memories is one of the significant cognitive processes in depression. This study aimed to examine the impact of autobiographical memory specificity training on depression and co-rumination in depressed female students of Isfahan University in 2018.

Methods: The research was semi-experimental and designed using the pre-test and post-test for both experimental and control groups with a two-month follow-up period. Twenty depressed female students were selected as purposive sampling, and they were randomly assigned to two groups of experimental and control. The research tools were the Beck Depression Inventory (BDI-II) and Co-Rumination Questionnaire (CQ). The experimental group underwent autobiographical memory specificity training for five sessions per week, and the control group received no intervention. The data were analyzed using analysis of covariance.

Results: According to the results of the research, the autobiographical Memory Specificity Training led to improved depression in the experimental group in the post-test $(\mathrm{P}>0.05)$ and follow-up $(\mathrm{P}<0.05)$. Consequently, the results showed that the autobiographical memory specificity training had no significant effect on the experimental group's co-rumination scores in the post-test and follow-up.

Conclusion: Generally, it can be concluded that autobiographical Memory Specificity Training is an effective way to reduce depression. Due to the ease and a low number of sessions, this training can be used along with other treatments to reduce the vulnerability to depression.

Citation: Poursaeid Esfahani M, Tavakoli M, Taher Neshatdost H. The effectiveness of autobiographical memory specificity training on depression and co-rumination in depressed students. Advances in Cognitive Sciences. 2020;22(1):25-35. 
D)

\title{
تأثير آموزش اختصاصىسازى حافظه سر كذشتى بر افسردى و نشخوار فكرى اشتر اكى در دانشجويان افسرده
}

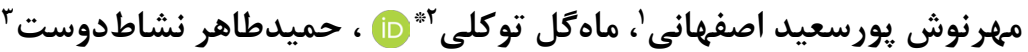

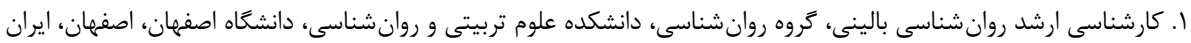

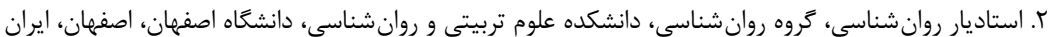

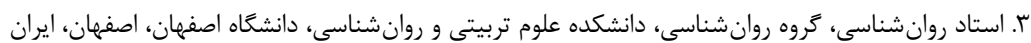

\section{ars}

\begin{abstract}
مقدمه: كاهش خاص بودن حافظه به عنوان يكى از فرآيندهاى شناختى اصلى در افسردىى مطح شده است. هدف يزوهش حاضر بررسى تأثير آموزش اختصاصىسازى حافظه سركذشتى بر افسردىى و نشخوار فكرى اشتراكى در دانشجويان
\end{abstract}

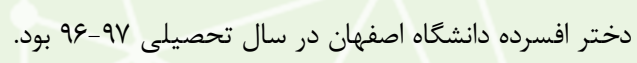

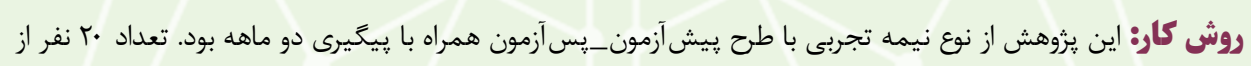
دانشجويان دختر افسرده به شيوه هدفمند انتخاب شدند و سيس به صورت تصادفى در دو كروه آزمايش و كنترل قرار داده

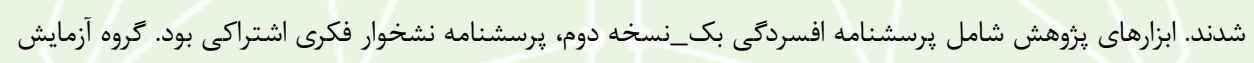
آموزش اختصاصىسازى حافظه سركذشتى را به مدت ه جلسه هفتكى، دريافت كردند و گروه كنترل هيج مداخلهاى دريافت نكرد. تحليل دادهها با استفاده از روش تحليل كوواريانس انجام گرفت. يافته ها: بر طبق نتايج، آموزش اختصاصىسازى حافظه سركذشتى منجر به بهبود افسردگى در مرحله يسآزمون و

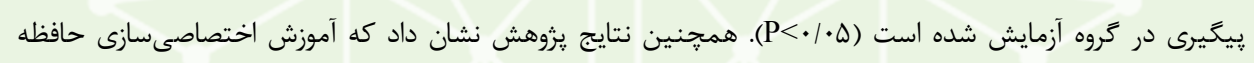
سرگذشتى تأثير معنادارى بر نشخوار فكرى اشتراكى گروه آزمايش در مرحله يٍ آزمون و پييخيرى نداشته است. نتيجه كَيرى: به طور كلى، مى توان نتيجه كرفت كه آموزش اختصاصىسازى حافظه سرگذشتى روش مؤثرى براى كاهش افسردگى است و با توجه به سهولت و تعداد كم جلسات اين آموزش، مى توان از آن در كنار ساير درمانها براى كاهش آسيب يذيرى به افسردگى سود جست.
دريافت:

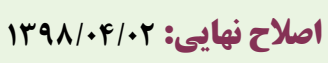

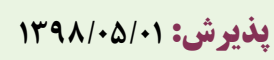

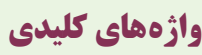
افسردگى آموزش اختصاصىسازى حافظه حافظه سر كذشتى احتصى نشخوار فكرى اشتراكى ستى ستى

نويسنله مسئول ماهكل توكلى، استاديار روانشناسى، كروه روانشناسى، دانشكده علوم تربيتى و روانشناسى، دانشگاه اصفهان، اصفهان، درون

ايميل:M.tavakoli@edu.ui.ac.ir

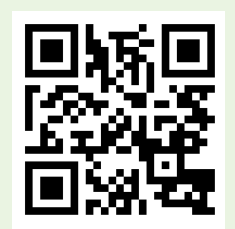

do

doi.org/10.30699/icss.22.1.25

مقلdمه

مى برند، اثر منفى مى گذارند (ّ). در ايران نيز افسردگى در جمعيتهاى

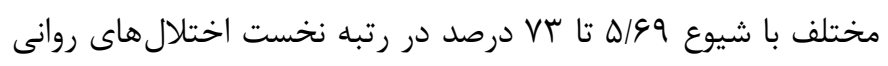
قرار دارد كه در تمام سنين و هر دو جنس ديده مى شود (Y)، اما با اين حال شيوع آن در زنان دو برابر مردان است (ه). اين اختلال از نوسانات

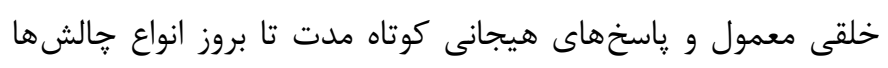

اختلال هاى افسردگى از رايجترين اختلالهاى روان يزشكى هستند كه در بزرگسالان روى مى دهند (1) و با احساس غم و اندوه، عدم علاقه به

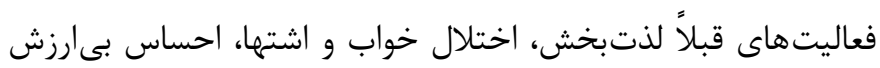
بودن و گاه افكار مرگ شناخته مىشود (؟). همه اختلال هاى افسردگى بسيار ناتوان كننده هستند و بر كيفيت زندكى كسانى كه از آن رنج 
نشخوار فكرى اشتراكى با افزايش سن در آنها افزايش مى يابد (YI).

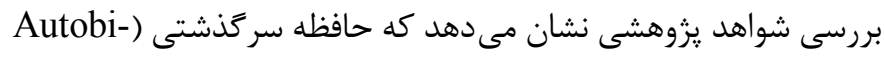
يكى ديخر از عوامل مرتبط با افسردگى است.

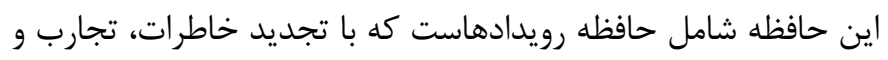

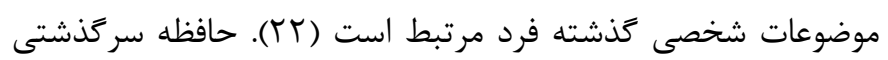

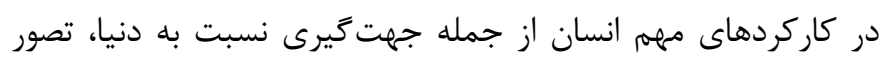

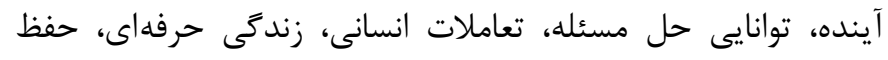

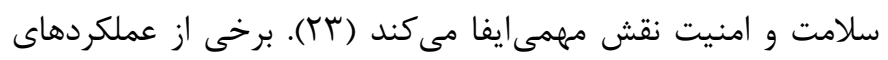
حافظه سركذشتى را مىتوان در سه حيطه عملكردهاى رهنمودى، عملكردهاى اجتماعى و عملكردهاى مرتبط با خود جاى داد. عملكرد مرتبط با خود به تاثير اين حافظه در تحول شخصيتى و ايجاد حسى إنى

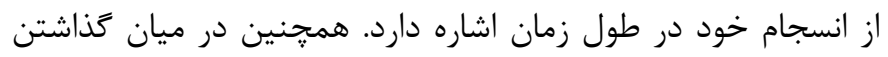

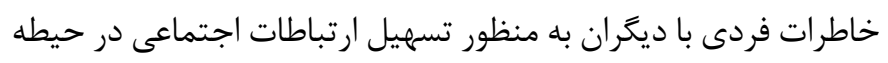

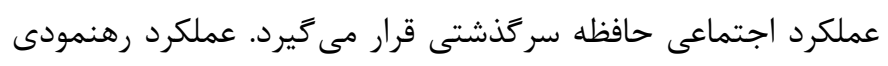

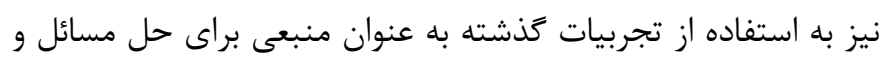

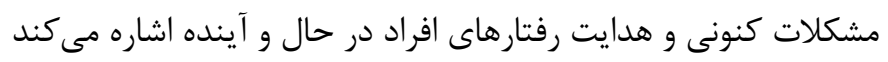

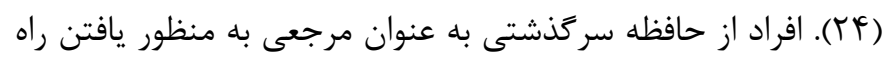

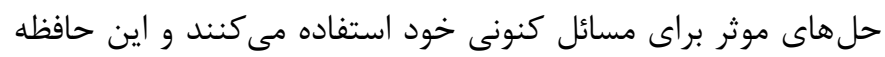
نقش حائز اهميتى در فرآيند حل مسئله دارد (TD). حافظه سر كذشتى

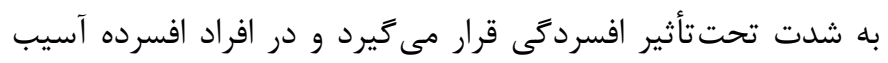

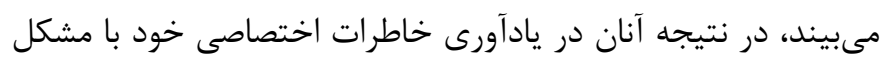

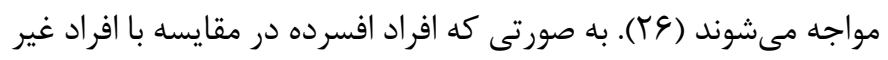
افسرده خاطرات سر كذشتى اختصاصى را به دشوارى بازيابى مى منمايند

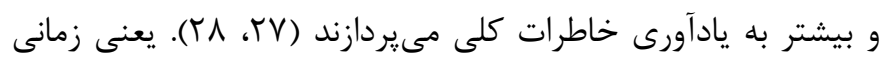

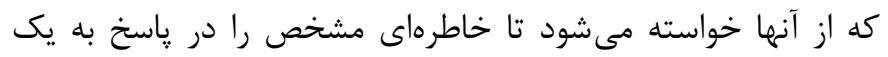

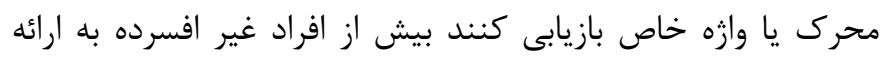

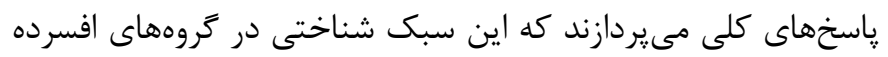

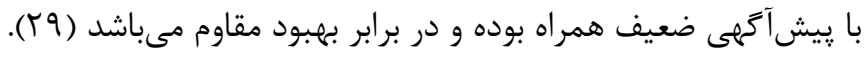

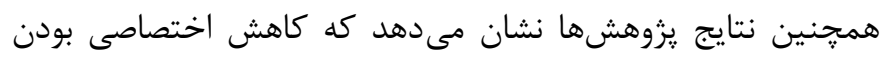

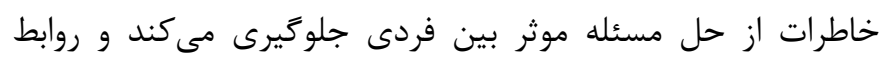

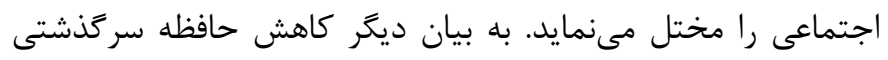

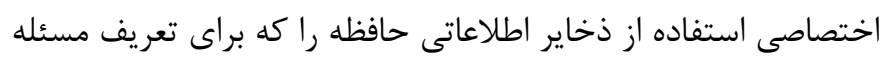

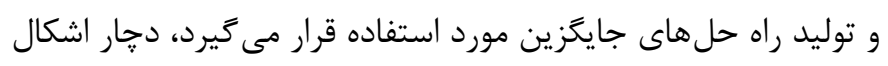

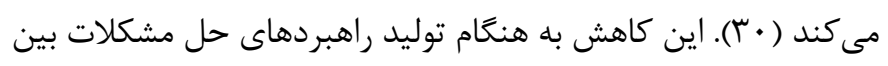

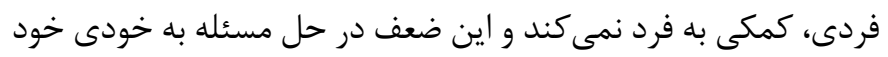

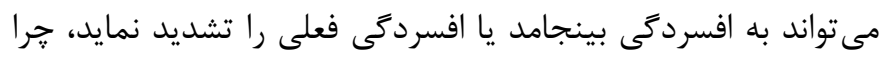

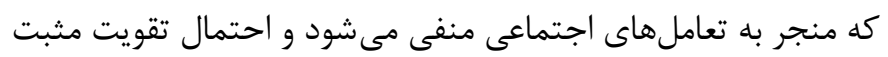

در زندگى روزمره افراد متفاوت است و با شمارى از ييامدهاى منفى

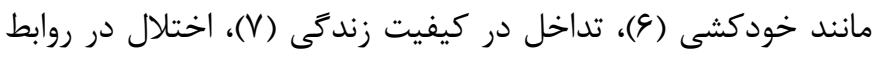

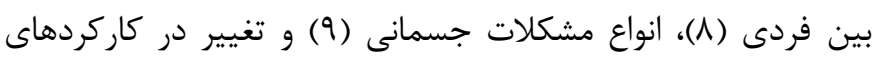

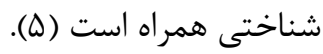

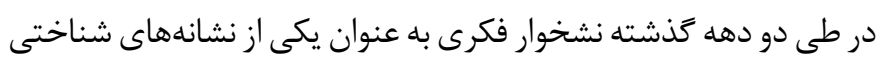

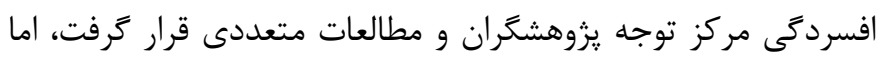

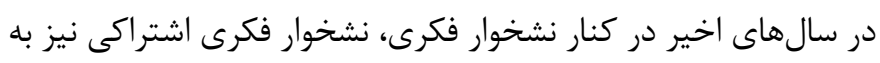

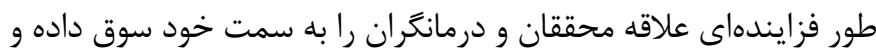

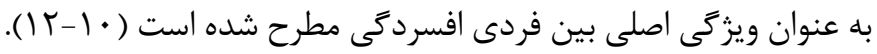
نشخوار فكرى اشتراكى، صحبت كردن بيش از حد با يك دوست نزديك در مورد مشكلات و مسائل شخصى است و شامل تشويق دو جانبه براى

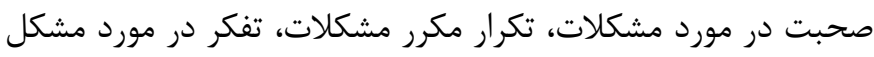

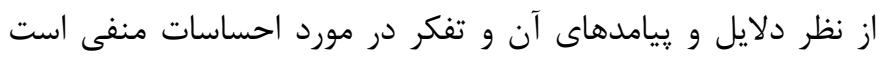

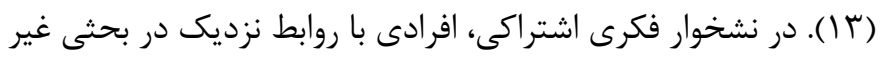
متمركز بر يافتن راهحل شركت مىكنند و بر تفكر در مورد مسائل و و

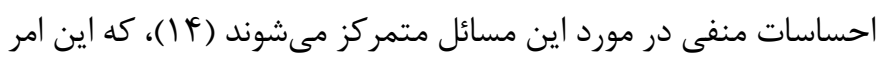

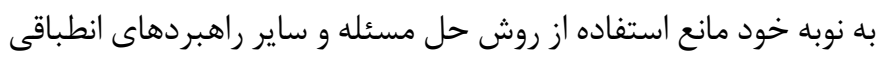

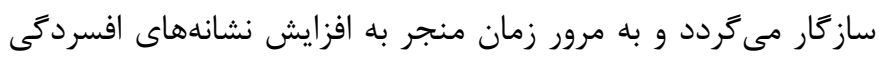

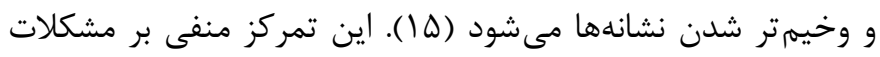

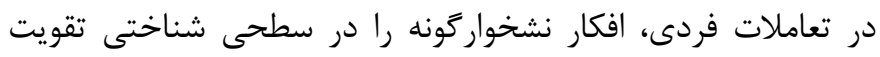
مى كند. در واقع نشخوار فكرى اشتراكى شبيه نشخوار فكرى است زئر زيرا

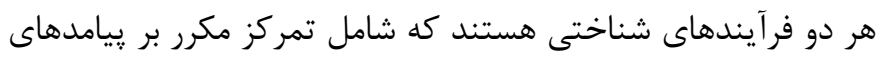

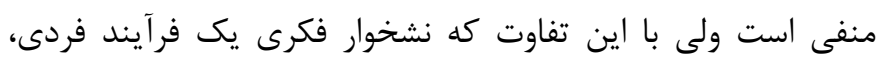

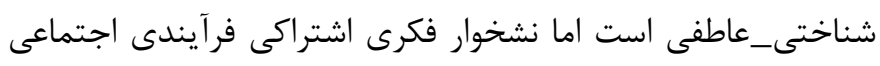

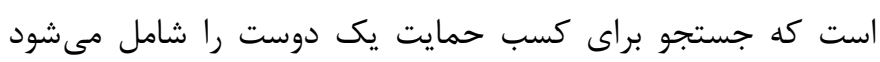

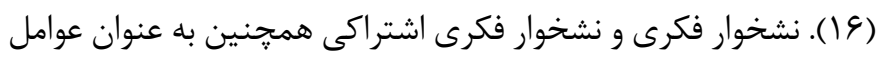

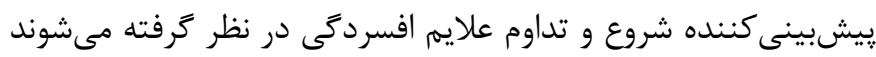

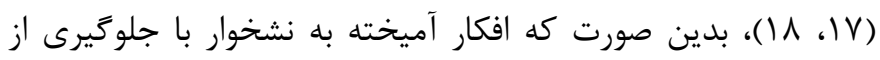

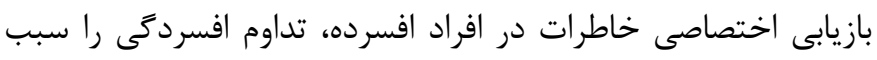

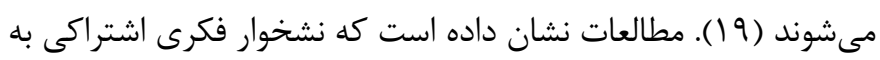

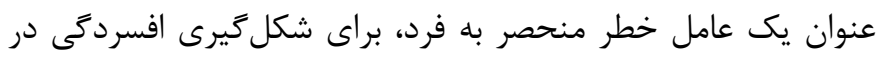

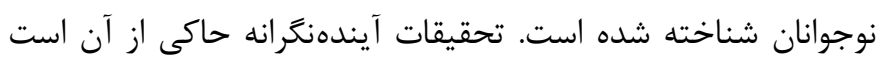

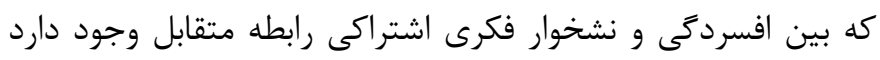

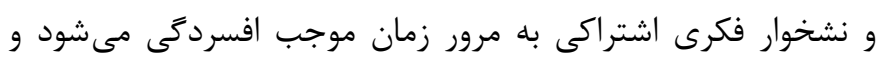

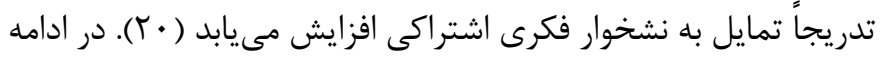
بررسى شواهد تجربى نشان داده است كه دختران نسبت به يسران

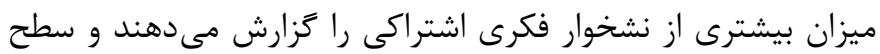


روش نمونه گيرى هدفمند تعداد •r نفر از آنان با توجه به ملاكهاى

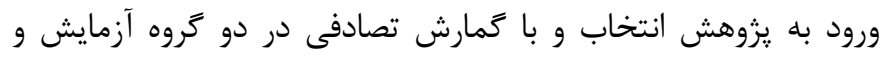

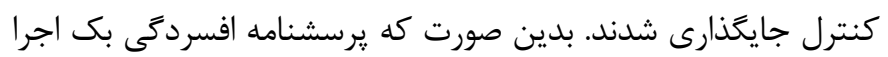

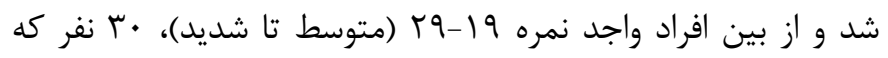

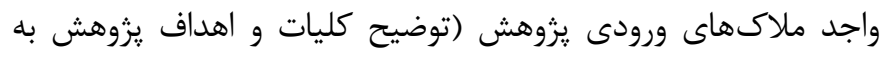
منظور كسب رضايت آكاهانه براى شركت در جلسات، تحصيل در مقطع

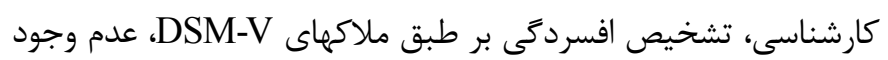

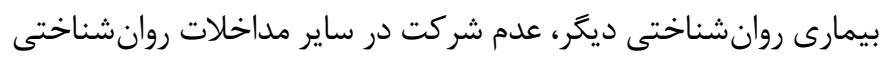

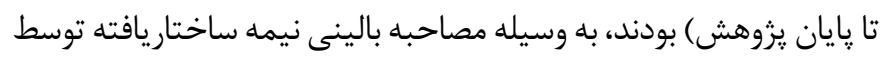

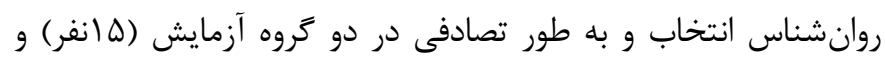

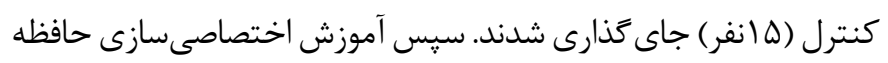

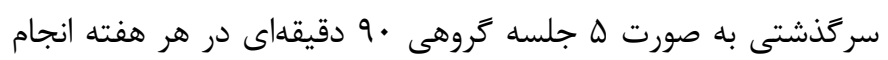
شد و ساختار كلى جلسات مطابق با آموزش اختصاصى سازى خاطر هرات

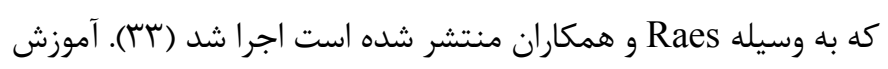

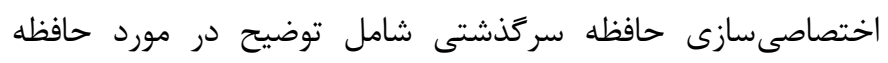

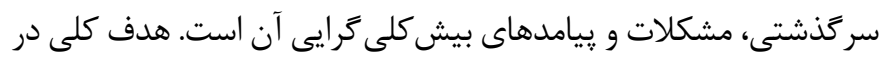

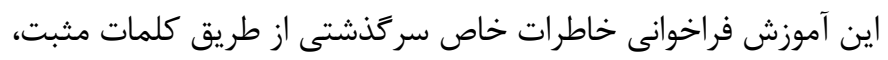

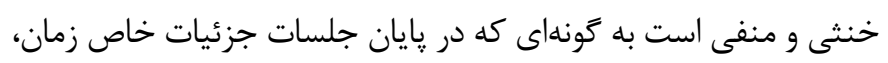
مكان و زمينه حسى حوادث فردى از حافظه بازيابى شود.

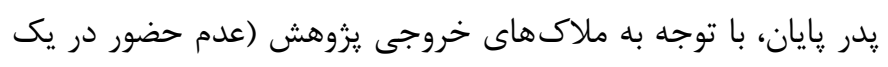

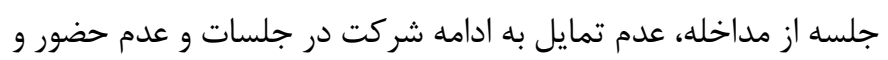

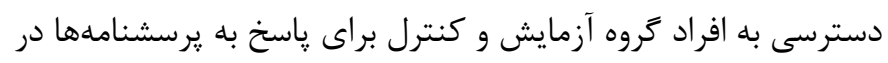

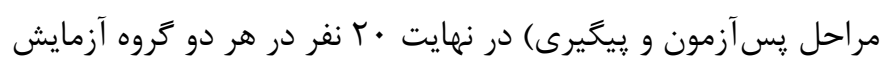

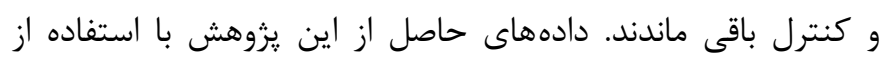

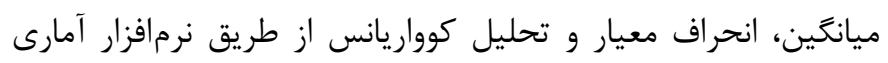

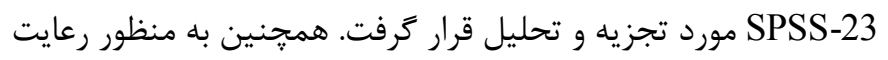
اخلاق يزوهش اين مداخله براى اعضاى گروه كنترل نيز اجرا كرديد.

\section{يرسشنامه افسردكى بك (BDI-II))}

Beck

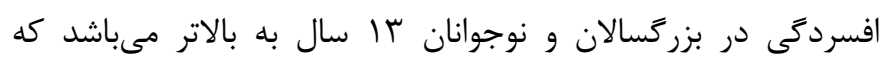

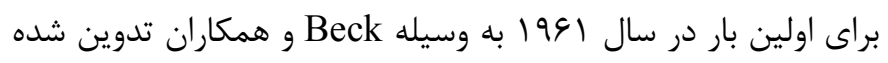

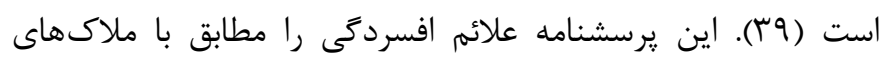

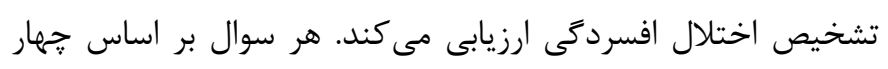

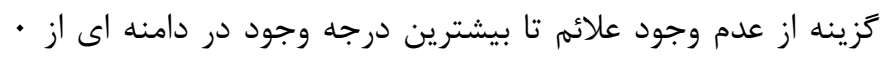

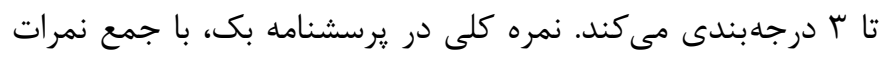

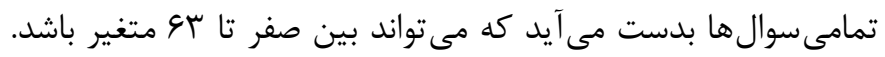

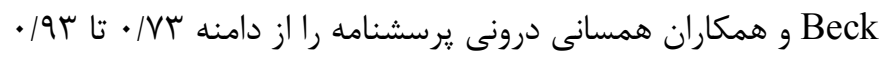

اجتماعى را كاهش مى دهد (آ). علاوه بر اين حافظه بيش كلى ترا

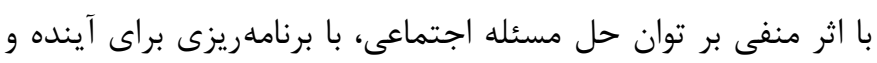

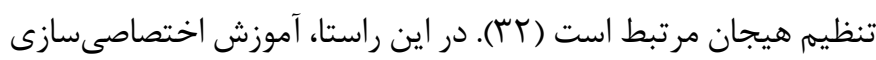

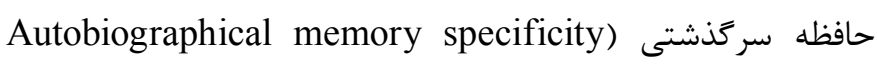
(training با آموزش فر آيند بازخوانى خاطرات سر كذشتى شخصى از حافظه به طريقى است كه هم خاطرات مثبت و خنثى و هم خاطرات

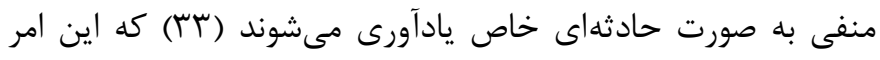
به افزايش بازيابى اختصاصى خاطرات، كاهش بيش كلى دادئى

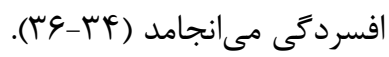

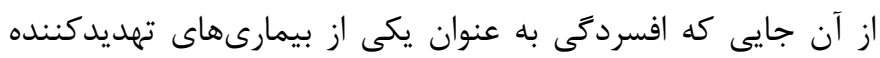

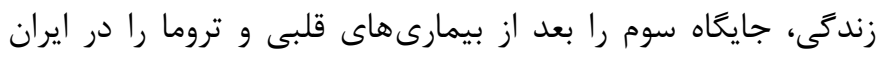

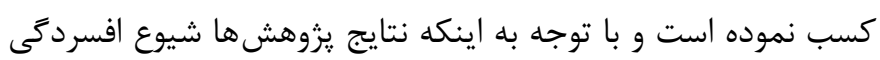

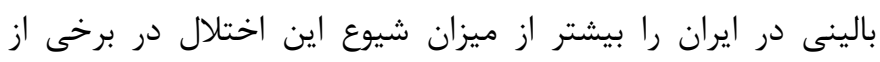

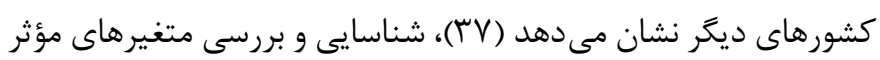

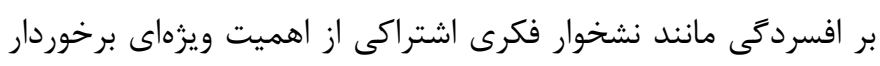

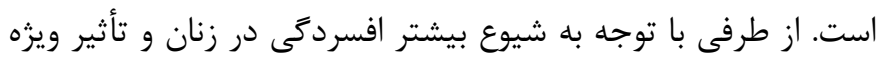

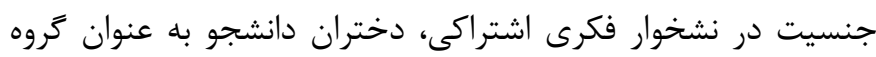

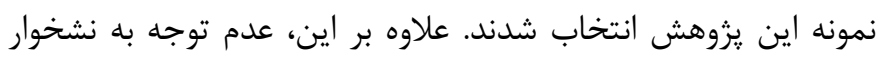

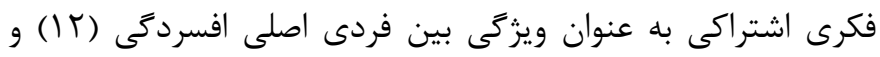

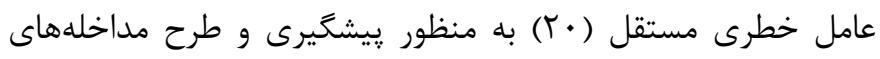

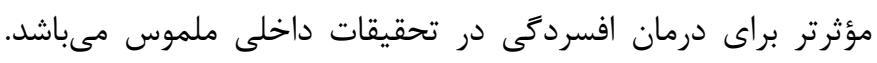

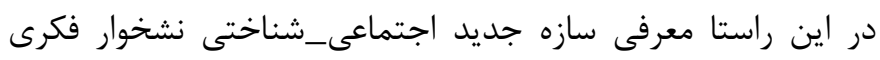

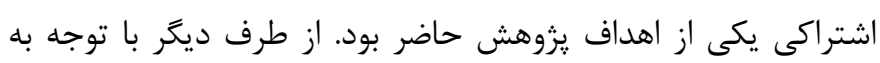

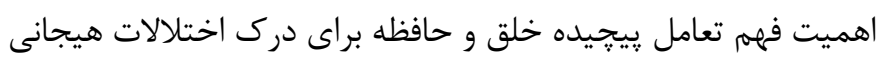

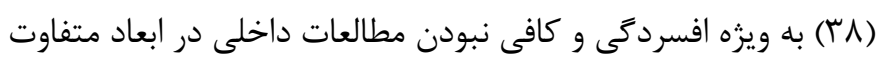
اثربخشى آموزش اختصاصىسازى حافظه سركذشتى بر جمعيته آنهاى

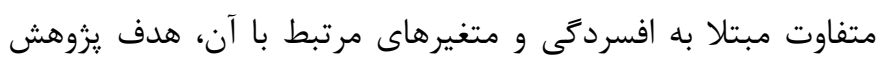

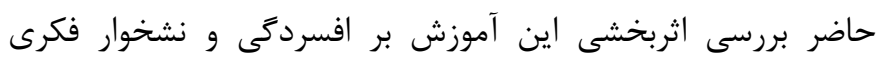
اشتراكى در دانشجويان دختر افسرده بود.

\section{روش كار}

يزوهش حاضر از نوع نيمه تجربى با طرح بيش آزمون_يس آزمون همراه

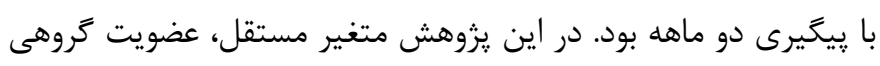

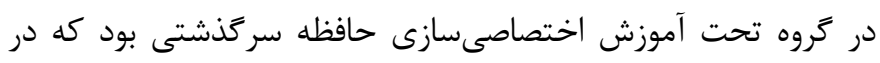

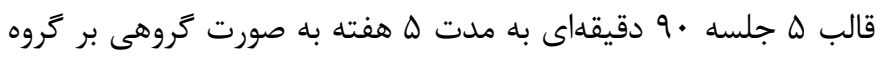

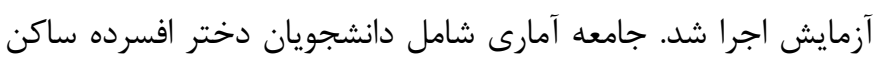
در خوابخاههاى دانشخاه اصفهان در سال تحصيلى 
در روابط دوستى همجنس ها توسط Rose در سال r +. ب طراحى شده است (YF). هر عبارت آن در مقياسى ه درجهاى، ياسخ داده مىشود. نمرهگذارى اين يرسشنامه به اين صورت است كه امتياز خردهمقياسها با هم جمع مىشوند و نمره نهايى براى اين VV آيتم منعكس كننده سطح كلى نشخوار فكرى اشتراكى است. Rose و همكاران ثبات درونى كافى، قابليت اطمينان خوب آزمون، بازآزمايى و اعتبار خوب مقياس

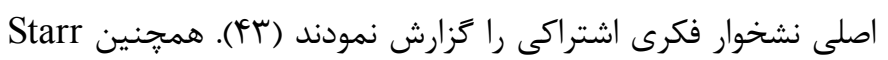
و Davila آلفاى كرونباخ اين يرسشنامه را ه9/. Fزارش كردهاند (FF). Ciesla (هأ). در ايران نيز Piraman و همكاران پس از هنجاريابى برسشنامه، مقدار آلفاى كرونباخ 99/• را براى كل :رسشنامه به دست آورند (• (1).

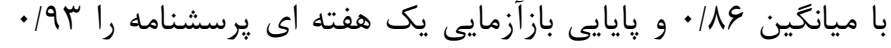
كزارش كردند. آنها همسانى درونى يرسشنامه فوق را براى بيماران

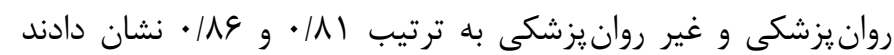

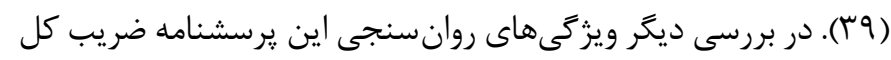

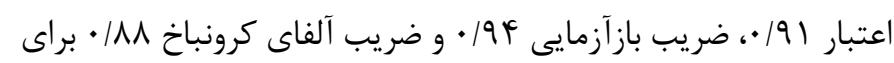

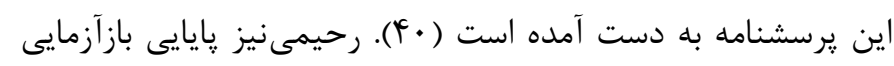
|VA •، ضريب آلفاى كرونباخ AVI • و روايى همزمان خوبى را براى اين يرسشنامه در دانشجويان بدست آورد (1) (1). questionnaire (CQ)) يرسشنامه نشخوار فكرى اشتراكى Co-rumination گزارشى VY كزينهاى است كه براى ارزيابى ميزان نشخوار فكرى اشتراكى

جدول ا. محتواى جلسات

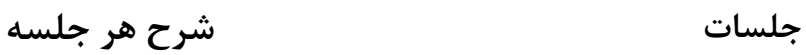

\begin{tabular}{|c|c|}
\hline 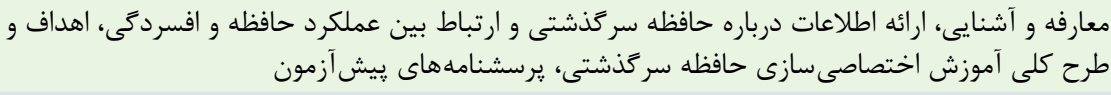 & 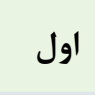 \\
\hline تمرين خاصتر كردن خاطرات با كلمات خنثى & 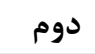 \\
\hline تمرين خاصتر كردن خاطرات با كلمات مثبت & 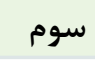 \\
\hline تمرين خاصتر كردن خاطرات با كلمات منفى & جههارم \\
\hline تمرين تفكيك بين انواع خاطرات سركذشتى، يرسشنامههاى يسآزمون & 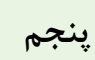 \\
\hline
\end{tabular}

يافته ها

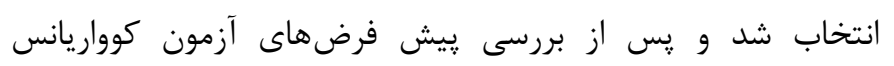

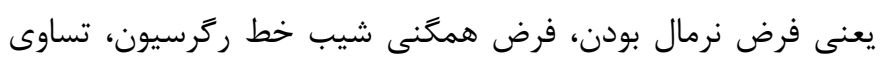

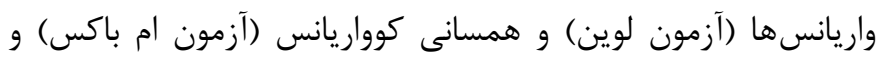

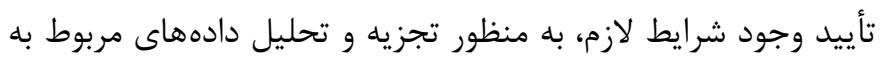
تفاوت بين دو گروه آزمايش و كنترل از لحاظ متغير افسردى لَّى و نشخوار فكرى اشتراكى از اين روش بهره كرفته شد.

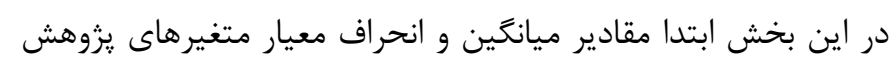

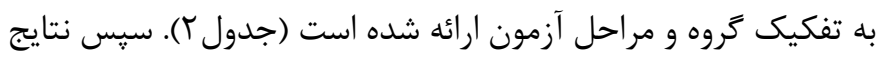

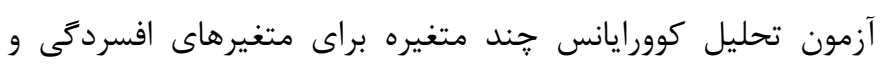

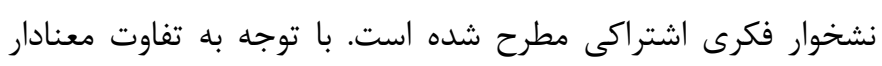

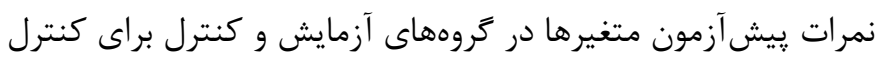

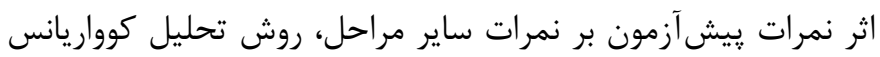

جدول r. شاخصهاى توصيفى

\begin{tabular}{|c|c|c|c|c|c|}
\hline \multicolumn{2}{|c|}{ كنترل (•ln } & \multicolumn{2}{|c|}{ آزمايش (•ln=) } & \multirow{2}{*}{ ارزيابى حرله } & \multirow{2}{*}{ متغيرها } \\
\hline انحراف معيار & ميانغين & انحر اف معيار & ميانغين & & \\
\hline$r / 90$ & $r / v \cdot$ & $r / r$. & $r F / r$. & ي بيش آزمون & \multirow{3}{*}{ افسردَى } \\
\hline V/rr & $19 / 4$. & $9 / 1 \Lambda$ & $1 \% / \Lambda$ & 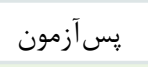 & \\
\hline SINA & $r r / Q$. & $N \cdot r^{2}$ & $\mid r / 9$. & بيخيرى & \\
\hline TYMT & $v \varepsilon / 0$. & IV/DF & $9 \Delta / r$. & يسآزمون & \multirow{3}{*}{ نشخوار فكرىاشتراكى } \\
\hline$r \cdot 199$ & $\wedge 1 / 1$. & $19 / \pi r$ & $4 \cdot / 4$. & يِش آزمون & \\
\hline TV/IF & $\Delta V / \cdot \cdot$ & $T F / \pi$ & 9.19 . & بيكيرى & \\
\hline
\end{tabular}


بيخيرى ناشى از عضويت گَروهى است.

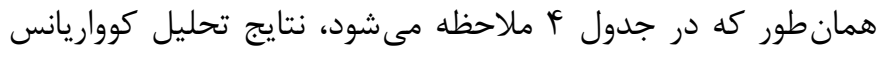

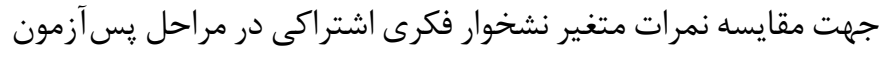

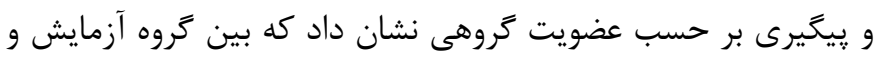

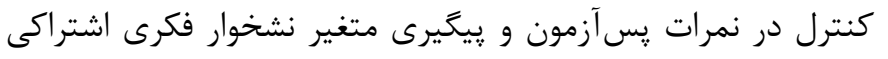
تفاوت معنادارى وجود ندارد (ه •/P> (P).
همانطور كه در جدول ب ملاحظه مىشود، نتايج تحليل كوواريانس جهت مقايسه نمرات متغير افسردىى در مراحل پس آزمون و وِيخيرى بر حسب عضويت گروهى نشان داد كه بين گروه آزمايش و كنترل در

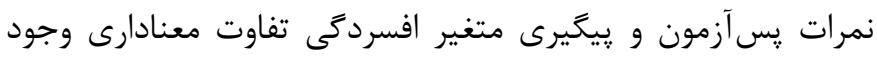

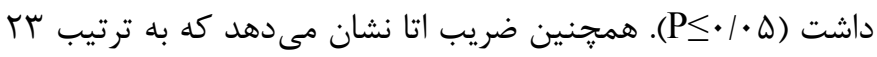

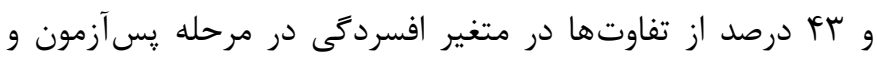

جدول ؟. نتايج آزمون تحليل كوررايانس حند متغيره جهت مقايسه كروههاى يزوهش در نمرات متغير افسردىى

\begin{tabular}{|c|c|c|c|c|c|c|c|}
\hline مجذور اتا & $\mathbf{P}$ & $\mathbf{F}$ & مجذانگين & درجه & مجذورات مجموع & منابع تغيير & متغير هاى وابسته \\
\hline$\cdot|r|$. &.$/ .14$ & V/GYG & TAI/VIV & 1 & TAINIV & يس آزمون & \multirow{2}{*}{ ييش آزمون افسردكى } \\
\hline$\cdot / l \Delta V$ & .1 .94 & $\Gamma / \Lambda \Delta \Delta$ & $|\Delta V / r \cdot|$ & 1 & $|\Delta V / r \cdot|$ & ييخيرى & \\
\hline 政 &.$/ \cdot r r$ & $\Delta / / F \Delta$ & $19 \cdot 1 \cdot 81$ & 1 & $19 \cdot 1 \cdot 01$ & ع لِس آزمون & \multirow{2}{*}{ عضويت گروهى } \\
\hline \multirow[t]{3}{*}{ אז4א. } & $. \cdot . r$ & $|r / 99|$ & $\operatorname{seg}(\pi)$ & 1 & sषg/rII & يِيرى & \\
\hline & & & rq/9q. & iv & GTV/aAT & يس آزمون & \multirow{2}{*}{ خطا } \\
\hline & & & $4 q / \wedge \Delta q$ & IV & $\Lambda F V / \Delta q q$ & ي بيخيرى & \\
\hline
\end{tabular}

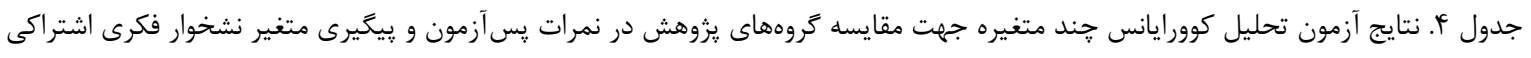

\begin{tabular}{|c|c|c|c|c|c|c|c|}
\hline مجذور اتا & $\mathbf{P}$ & $\mathbf{F}$ & مجذانگين & درجه & مجذوروات & منابع تغيير & متغير هاى وابسته \\
\hline . MFY & /..r & $1 \pi / 909$ & $\Delta \cdot r \varepsilon / q \cdot V$ & 1 & $\Delta \cdot r \varepsilon / 9 \cdot V$ & ِي آزمون & \multirow{2}{*}{ فيش آزمون نشتراكى اشخوار } \\
\hline$\cdot \mid r 11$ & . & V/G9T & rVII/\&Vr & 1 & rVII/GVr & يَيَيرى & \\
\hline$\cdot / \cdot \wedge V$ & . RTr & $1 / 911$ & $q C \cdot|\Lambda \Delta|$ & 1 & $g q \cdot|\wedge \Delta|$ & يس آزمون & \multirow{2}{*}{ عضويت كروهى } \\
\hline$\cdot 119$ & $\cdot 1 \cdot 19$ & r/TFV & $\mid \Delta V \Psi / \cdot Y \Psi$ & 1 & $\mid \Delta V r / \cdot T F$ & ييكيرى & \\
\hline & & & $r q v / q \cdot \Delta$ & IV & GVGF/MqT & يس آزمون & \multirow{2}{*}{ خطا } \\
\hline & & & FAF/FTD & IV & NTrS/TrV & ييكيرى & \\
\hline
\end{tabular}

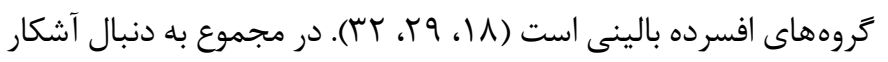

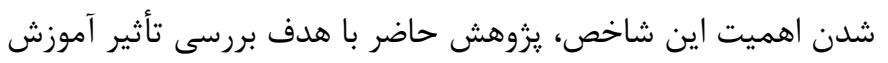

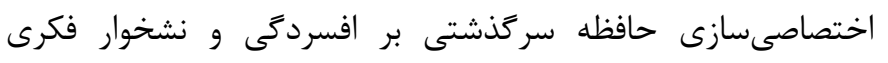
اشتراكى در دانشجويان دختر افسرده انجام شد.

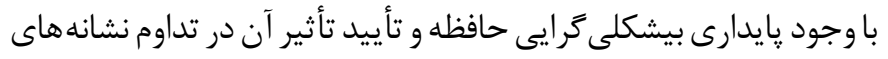

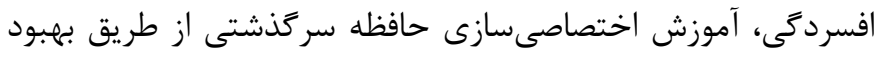

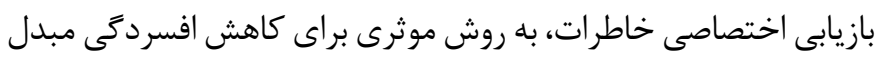

يكى از جدىترين اختلالهاى روانى افسردگى است، اختلالى كه يك

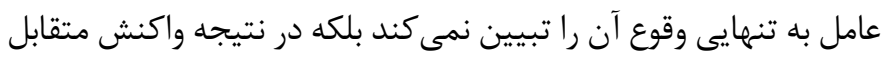

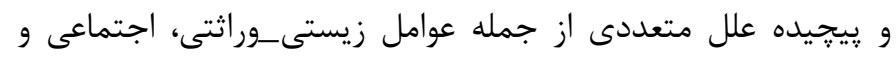

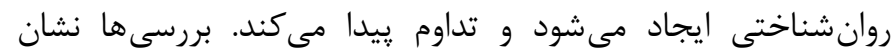
مى دهد كه كاهش خاص بودن حافظه سر كذشتى يك ويزگى شنى شناختى نشاندهنده آسيب يذيرى نسبت به افسردىى در كروههاى غير بالينى

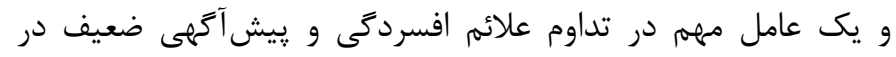


آمده از اين يزوهش و ساير مطالعات يِيشن مشخص مى كند كه آموزش

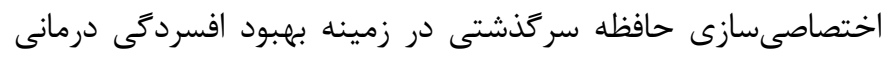
با تعداد جلسات محدود، ارزان قيمت و نويد بخش است كه با وجود

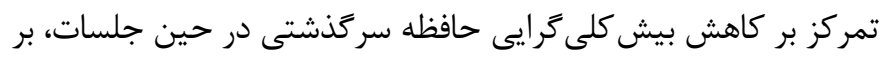

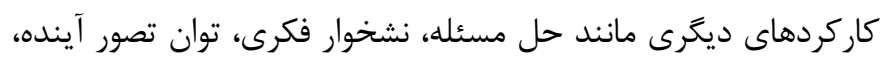

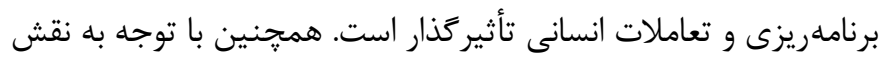

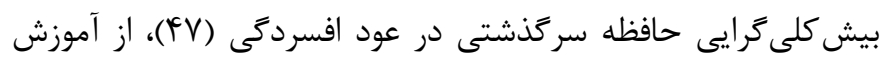

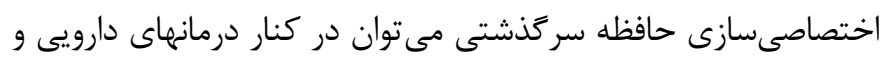
شناختى_رفتارى براى جلوكيرى از عود و كاهش نشانهاى افسردىى

متغير ديكر مورد بررسى در اين يزوهش نشخوار فكرى اشتراكى بود.

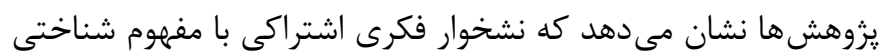

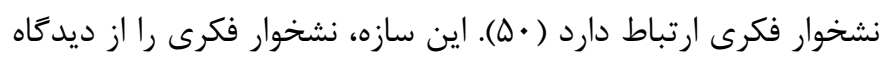

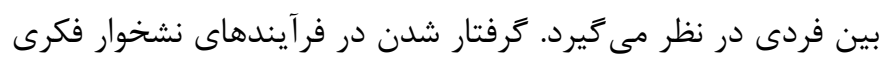

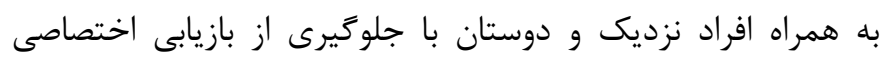

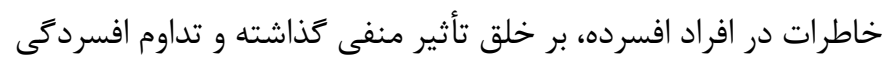
را موجب مى شود (9 ). از طرف ديخر با توجه به كاهش ارتباط نشخوار فكرى اشتراكى و علائم افسردىى به هنكام كنترل نشخوار فكرى،

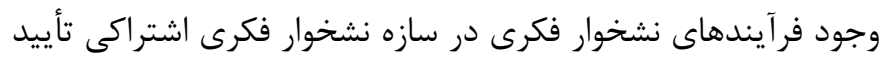
شده است (91). در اين راستا با توجه به نقش بيش كلى ترايى حافظه

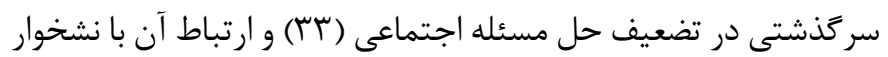

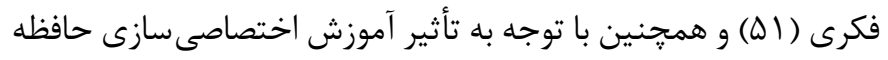
سركذشتى بر كاهش نشخوار فكرى و افزايش حل مسائل اجتماعى،

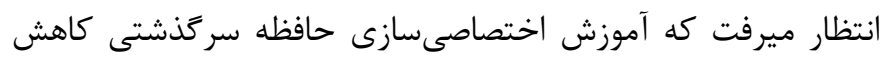
نشخوار فكرى اشتراكى را به دنبال داشته باشد اما نتايج تحليل كوواريانس نشان داد كه كاهش مشاهده شده در اين متغير معنادار

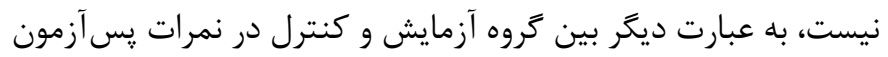
و پيخيرى متغير نشخوار فكرى اشتراكى تفاوت معنادارى از نظر كاهش اين متغير وجود ندارد. در تبيين اول از نتايج اين يزوهش مى توان

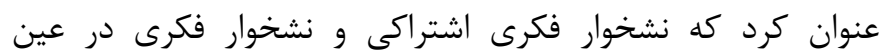

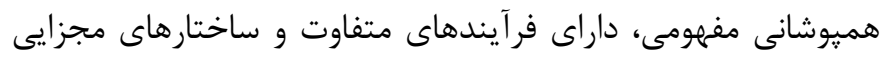

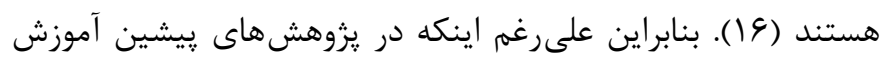
اختصاصىسازى حافظه سركذشتى، كاهش نشخوار فكرى مشاهده

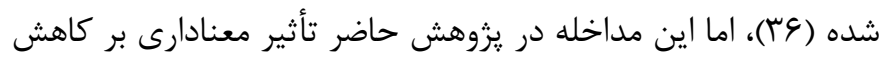

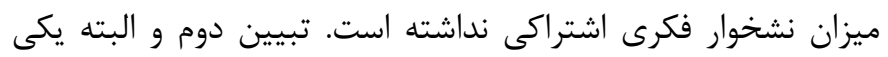
از مهمترين دلايل احتمالى يافته حاضر اين است كه با لحاظ كردن

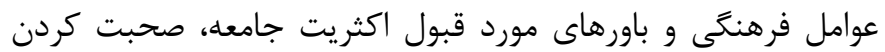

گَشته است (4)). در يى تمركز بر افزايش بازيابى اختصاصى خاطرات، از بيشكلى كرايى حافظه سركذشتى كاسته مىشود و در تلاش براى به خاطر آوردن جزئيات خاطرات كذشته، به مرور زمان افزايش

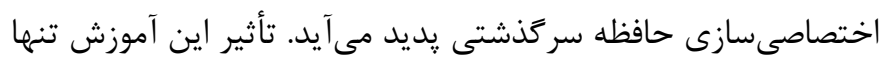

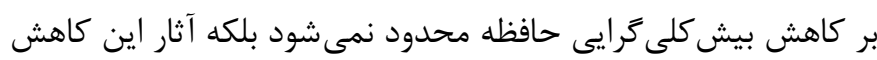

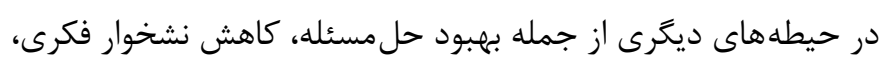
اجتناب شناختى، افزايش اميد و غيره آشكار مى شود (ع؟). در توضيح فرايند تأثير اين آموزش بر كاهش افسردگى مى توان بيان كرد كه با افزايش بازيابى اختصاصى خاطرات امكان دستيابى جزئىتر و بيشتر به منابع اطلاعاتى حافظه فراهم مى شود. در نتيجه، توليد راهحل هاى موثر إنى همراه با جزئيات خاص متناسب با موقعيت افزايش مىيابد كه اين امر فرافي

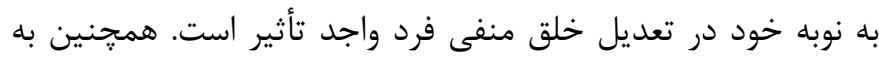

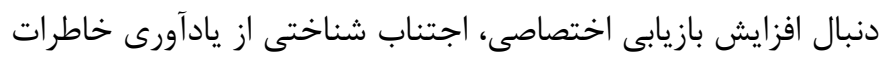

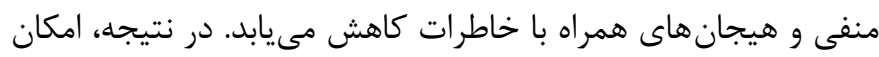

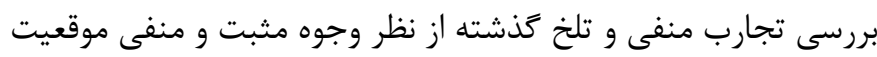

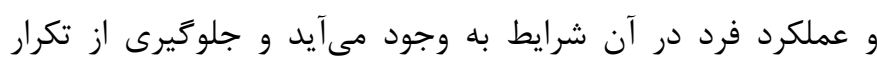
شكست و عملكرد ناموثر قبلى ممكن مى شود. همجنين به دليل رابطه دو سويه بين بيش كلى با افزايش اختصاصى شدن حافظه سركذشتى از ميزان نشخوار كاسته

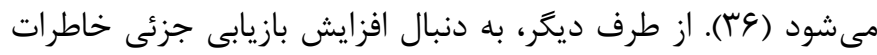

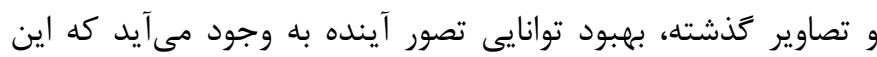

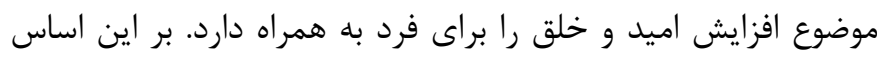

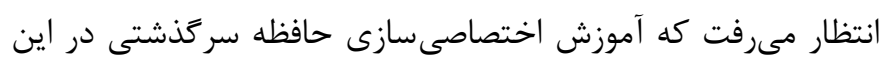

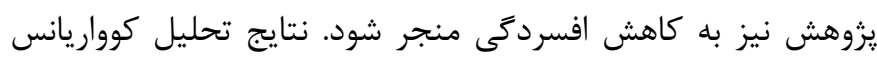

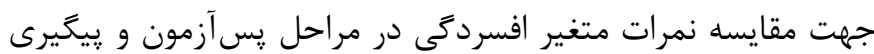
بر حسب عضويت كروهى نشان داد كه بين كروه آزمايش و كنترل در نمرات يس آزمون و پيخيرى افسردىى تفاوت معنادارى وجود دارد.

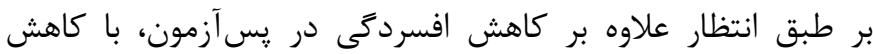

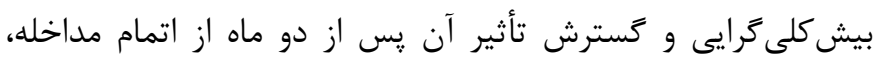

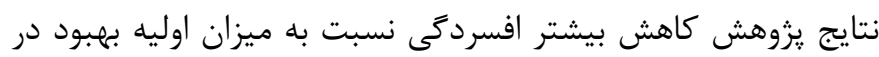

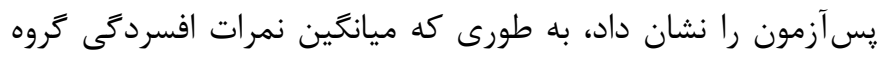

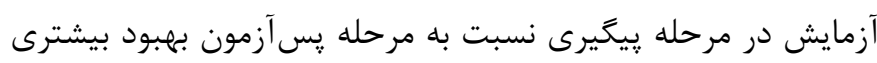

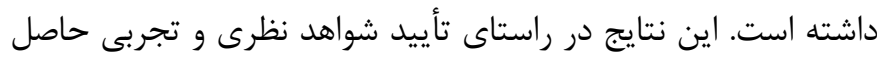
از يزوهش هاى Williams و همكاران (YV)، Raes و همكاران (سب)، Neshat-Doost Hitchcock

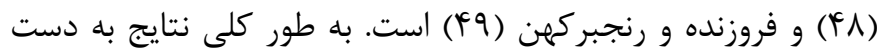


نتيجه كَفت كه براى افزايش كارآيى آموزش اختصاصسازى حافظه سركذشتى بر افسردى توجه به نقش اين سازه از اهميت ويزهاى برخوردار است. از مهمترين محدوديتهاى يزوهش حاضر مى توان به انجام مداخله

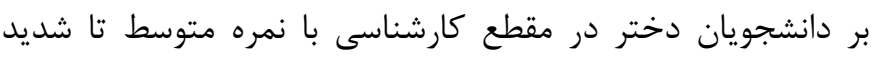
در يرسشنامه بك اشاره نمود كه تعميميذيرى نتايج يزوهش را به دانه

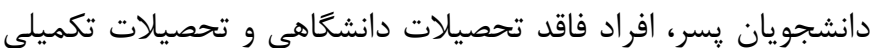
و افراد با نمرات متفاوت در يرسشنامه افسردگى بك با محدوديت همراه مىسازد. با توجه به محدوديتها و نتايج يزوهش پيشنهاد

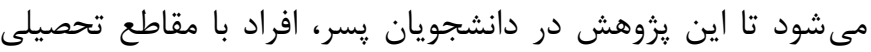
متفاوت و ساير طيفهاى يرسشنامه بك انجام شود.

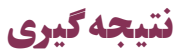

به طور خلاصه مى توان نتيجه كرفت كه آموزش اختصاصىسازى حافظه سر كذشتى براى كاهش افسردگى، درمانى كوتاه مدت و مقرون به صرفه است كه با حذشت هر جه بيشتر زمان و ادامه روند افزايش خاص شدن دائ حافظه، باعث بهبود بيشتر افسردىى مى شود. همجنين با توجه به اينكه در جلسات آموزش اختصاصى سازى حافظه سركذشتى بيشترين تمركز بر افزايش خاص شدن حافظه و خاطرات است، آموزش حاضر منجر به كاهش معنادار نشخوار فكرى اشتراكى نشد.

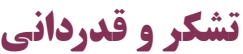

نويسنده مقاله بر خود لازم مى داند كه از كليه شركت كنندكان در يزوهش و نيز از ستاد توسعه علوم و فناورىهاى شناختى كه حمايت مالى از اين يروهش را بر عهده كرفتند، تشكر و قدردانى نمايد. شايان ذكر است كه اين مقاله حاصل كار קاياننامه دوره كارشناسى ارشد در دانشخاه اصفهان است.

\section{References}

1. Waraich P, Goldner EM, Somers JM, Hsu L. Prevalence and incidence studies of mood disorders: a systematic review of the literature. The Canadian Journal of Psychiatry. 2004;49(2):124-138. 2. Hybels CF, Blazer DG, Pieper CF, Landerman LR, Steffens DC. Profiles of depressive symptoms in older adults diagnosed with major depression: Latent cluster analysis. The American Journal of Geriatric Psychiatry. 2009;17(5):387-396.

3. Pincus HA, Pettit AR. The societal costs of chronic major
با دوستان در مورد مشكلات براى برخى از افراد جز عادات زندَيشان محسوب مىشود. اين ديد به نشخوار فكرى اشتراكى باعث مى شود تا افراد به عنوان راهكارى جهت رهايى از مشكلات و هيجانات منفى به

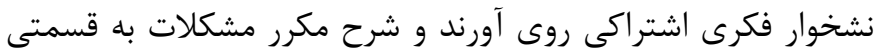
از زندكى روزانه اين افراد تبديل شود. در تفسير ديكرى از يافته

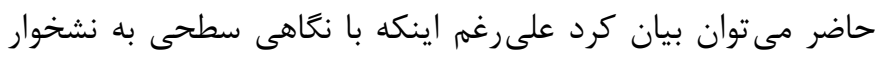
فكرى اشتراكى، در وهله اول به عنوان يكى فرآيند اجتماعى حمايتى مثبت به نظر مى رسد، اما آنجه در واقع به مرور از آن يديدار مى گرىدد شكل كيرى، تشديد و تداوم خلق افسرده است (أl). در نتيجه با توجه به اينكه در جلسات آموزش اختصاصى سازى حافظه سركذشتى بيشترين تمركز بر افزايش جزئيات و اختصاصىسازى خاطرات است و در حين مداخله به طور مستقيم به توضيح نشخوار فكرى اشتراكى، ييامدهاى آن و ارائه راهكار براى خروج و يا جلوكيرى از مباحث

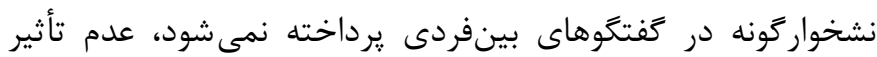
معنادار آموزش حاضر بر نشخوار فكرى اشتراكى قابل توجيه است. همجنين در آخرين تبيين از اين نتيجه مىتوان بيان نمود كه با توجه به جنسيت نمونه يزوهش و واكنش يذيرى بالاى دختران نسبت به رويدادهاى بين فردى منفى، عدم كاهش معنادار اين متغير به دليل عادت به استفاده از نشخوار فكرى اشتراكى به عنوان روشى براى

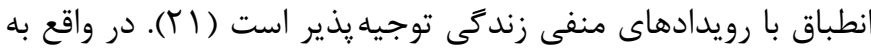

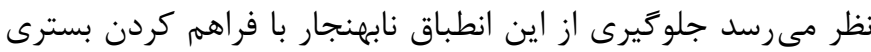
براى افزايش آكاهى در جهت تغير نوع نعاه و باورها نسبت به نشخوار

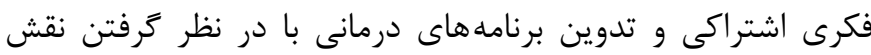

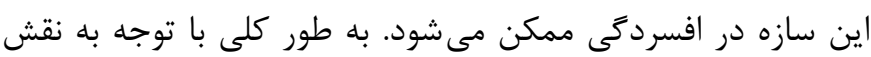
نشخوار فكرى اشتراكى به عنوان ويزگى اصلى بينفردى افسردىى و عامل خطرى منحصر به فرد در ايجاد و تداوم افسردگى، مى توان

depression. The Journal of Clinical Psychiatry. 2001;62(Supp16):5-9.

4. Montazeri A, Mousavi SJ, Omidvari S, Tavousi M, Hashemi A, Rostami T. Depression in Iran: A systematic review of the literature (2000-2010). Payesh. 2013;12(6):567-594. (Persian) 5. Sadock BJ, Sadock VA, Ruiz P. Kaplan and Sadock's Synopsis of Psychiatry: Behavioral Sciences/Clinical Psychiatry. 11th ed. New York:Wolters Kluwer;2014. 
6. Hawton K, i Comabella CC, Haw C, Saunders K. Risk factors for suicide in individuals with depression: A systematic review. Journal of Affective Disorders. 2013;147(1-3):17-28.

7. Berlim MT, McGirr A, Fleck MP. Can sociodemographic and clinical variables predict the quality of life of outpatients with major depression?. Psychiatry Research. 2008;160(3):364-371. 8. Zlotnick C, Kohn R, Keitner G, Della Grotta SA. The relationship between quality of interpersonal relationships and major depressive disorder: Findings from the National Comorbidity Survey. Journal of Affective Disorders. 2000;59(3):205-215.

9. Elderon L, Whooley MA. Depression and cardiovascular disease. Progress in Cardiovascular Diseases. 2013;55(6):511-523. 10. Piraman MJ, Tavakoli M, Torkan H. Rumination and co-rumination: Factors predicting depression. International Journal of Educational and Psychological Researches. 2016;2(2):99-104.

11. De Lissnyder E, Koster EH, Goubert L, Onraedt T, Vanderhasselt MA, De Raedt R. Cognitive control moderates the association between stress and rumination. Journal of Behavior Therapy and Experimental Psychiatry. 2012;43(1):519-525.

12. Rose AJ. Co-rumination in the friendships of girls and boys. Child Development. 2002;73(6):1830-1843.

13. Tompkins TL, Hockett AR, Abraibesh N, Witt JL. A closer look at co-rumination: Gender, coping, peer functioning and internalizing/externalizing problems. Journal of Adolescence. 2011;34(5):801-811.

14. White ME, Shih JH. A daily diary study of co-rumination, stressful life events, and depressed mood in late adolescents. Journal of Clinical Child \& Adolescent Psychology. 2012;41(5):598-610.

15. Landphair J, Preddy T. More than talk: Co-Rumination among college students. About Campus. 2012;17(3):18-22.

16. Funasaki, KS. Examining mediators of the maladaptive and adaptive effects of co-rumination. [PhD Thesis]. Washington:Seattle Pacific University;2012. p. 138.

17. Huffziger S, Ebner-Priemer U, Koudela S, Reinhard I, Kuehner C. Induced rumination in everyday life: Advancing research approaches to study rumination. Personality and Indi- vidual Differences. 2012;53(6):790-795.

18. Dam A, Roelofs J, Muris P. Correlates of co-rumination in non-clinical adolescents. Journal of Child and Family Studies. 2014;23(3):521-526.

19. Omidi A, Mohammad Khani P, Dolatshahi B, Poorshahbaz A. Efficacy of mindfulness based cognitive therapy and traditional cognitive behavior therapy in reduction of memory over generalization inpatients with major depressive disorder in 2007. Journal of Research in Behavioural Sciences. 2009;7(2):107-117. (Persian)

20. Stone LB, Hankin BL, Gibb BE, Abela JR. Co-rumination predicts the onset of depressive disorders during adolescence. Journal of Abnormal Psychology. 2011;120(3):752-757.

21. Stone LB. Co-rumination and Depression in Children [MS Thesis]. New York:State University of New York at Binghamton; 2009 .

22. Muenks K. Overgeneral memory as an emotion regulation strategy [PhD Thesis]. Ohio:The Ohio State University;2010. 23. Rendell PG, Henry JD, Phillips LH, De La Piedad Garcia X, Booth P, Phillips P, et al. Prospective memory, emotional valence, and multiple sclerosis. Journal of Clinical and Experimental Neuropsychology. 2012;34(7):738-749.

24. Bluck S, Alea N, Habermas T, Rubin DC. A tale of three functions: The self-reported uses of autobiographical memory. Social Cognition. 2005;23(1):91-117.

25. Kaviani H, Rahimi M, Rahimi-Darabad P, Naghavi HR. Overgeneral memory retrieval and ineffective problem-solving in depressed patients with suicidal ideation: Implications for therapy. Psychology \& Psychological Therapy. 2011;11(3):413-423.

26. Williams AD, Moulds ML. Cognitive avoidance of intrusive memories: Recall vantage perspective and associations with depression. Behaviour Research and Therapy 2007;45(6):1141-1153.

27. Williams JMG, Barnhofer T, Crane C, Herman D, Raes F, Watkins E, et al. Autobiographical memory specificity and emotional disorder. Psychological Bulletin. 2007;133(1):122-148. 
28. Whalley MG, Rugg MD, Brewin CR. Autobiographical memory in depression: An fMRI study. Psychiatry Research: Neuroimaging. 2012;201(2):98-106.

29. Peeters F, Wessel I, Merckelbach H, Boon-Vermeeren M. Autobiographical memory specificity and the course of major depressive disorder. Comprehensive Psychiatry. 2002;43(5):344-350.

30. Williams, JMG, Dritschel, BH. Emotional disturbance and the specificity of autobiographical memory. Cognition \& Emotion. 1988;2(3):221-234.

31. Hermans D, Raes F, Eelen P. Mood and memory: A cognitive psychology perspective. In: Corveleyn J, Luyten P, Blatt SJ. The theory and treatment of depression: Towards a dynamic interactionism model. Leuven:Leuven University Press;2005. pp. 43-66 32. Raes F, Hermans D, Williams JM, Demyttenaere K, Sabbe B, Pieters G, et al. Reduced specificity of autobiographical memory: A mediator between rumination and ineffective social problem-solving in major depression?. Journal of Affective Disorders. 2005;87(2-3):331-335.

33. Raes F, Williams JM, Hermans D. Reducing cognitive vulnerability to depression: A preliminary investigation of MEmory Specificity Training (MEST) in inpatients with depressive symptomatology. Journal of Behavior Therapy and Experimental Psychiatry. 2009;40(1):24-38.

34. Neshat-Doost HT, Dalgleish T, Yule W, Kalantari M, Ahmadi SJ, Dyregrov A, et al. Enhancing autobiographical memory specificity through cognitive training: An intervention for depression translated from basic science. Clinical Psychological Science. 2013;1(1):84-92.

35. Eigenhuis E, Seldenrijk A, Van Schaik A, Raes F, Van Oppen P. Feasibility and effectiveness of memory specificity training in depressed outpatients: A pilot study. Clinical Psychology \& Psychotherapy. 2017;24(1):269-277.

36. Hitchcock C, Mueller V, Hammond E, Rees C, Werner-Seidler A, Dalgleish T. The effects of autobiographical memory flexibility (MemFlex) training: An uncontrolled trial in individuals in remission from depression. Journal of Behavior
Therapy and Experimental Psychiatry. 2016;52:92-98.

37. Aghaei E, Abedi A, Jamali Pa Ghalee S. Meta-analysis of the effectiveness of cognitive-behavioral interventions on the rate of depression symptoms (Iran 2001-2010). Clinical Psychology \& Personality. 2012;2(6):69-80. (Persian)

38. Joormann J, Teachman BA, Gotlib IH. Sadder and less accurate? False memory for negative material in depression. Journal of Abnormal Psychology. 2009;118(2):412-417.

39. Beck AT, Steer RA, Brown GK. Beck depression inventory-II. San Antonio. 1996;78(2):490-498.

40. Rajabi Gh, Attari Y, Haghighi J. Factor analysis of Beck Inventory questions about male students of Shahid Chamran University of Ahvaz. Journal of Educational Sciences. 2001;8(34):49-66. (Persian)

41. Rahimi C. Application of the beck depression inventory-II in Iranian University students. Scientific Journal of Clinical Psychology \& Personality. 2014;2(10):173-188. (Persian)

42. Rose AJ. Co-rumination in the friendships of girls and boys. Child Development. 2002;73(6):1830-1843.

43. Rose AJ, Carlson W, Waller EM. Prospective associations of co-rumination with friendship and emotional adjustment: Considering the socioemotional trade-offs of co-rumination. Developmental Psychology. 2007;43(4):1019-1031.

44. Starr LR, Davila J. Clarifying co-rumination: Associations with internalizing symptoms and romantic involvement among adolescent girls. Journal of Adolescence. 2009;32(1):19-37.

45. Ciesla JA, Dickson KS, Anderson NL, Neal DJ. Negative repetitive thought and college drinking: Angry rumination, depressive rumination, co-rumination, and worry. Cognitive Therapy and Research. 2011;35(2):142-150.

46. Hauer BJ, Wessel I, Geraerts E, Merckelbach H, Dalgleish T. Autobiographical memory specificity after manipulating retrieval cues in adults reporting childhood sexual abuse. Journal of Abnormal Psychology. 2008;117(2):444-453.

47. Sabatelli PJ. Effectiveness of group cbt with memory specificity training and self-distancing in moderately depressed adults. South American Journal of Psychology. 2016;1(1):1-9. 
48. Sumner JA, Griffith JW, Mineka S. Overgeneral autobiographical memory as a predictor of the course of depression: A meta-analysis. Behaviour Research and Therapy. 2010;48(7):614-625.

49. Foruzandeh A, Ranjbar Kohan Z. Autobiographical memory and depression: A preliminary study. Studies of Psychology and Educational Sciences. 2016;8(2):31-42. (Persian)
50. Boren JP. Co-rumination partially mediates the relationship between social support and emotional exhaustion among graduate students. Communication Quarterly. 2013;61(3):253-267. 51. Raes F, Hermans D, Williams JM, Beyers W, Eelen P, Brunfaut E. Reduced autobiographical memory specificity and rumination in predicting the course of depression. Journal of Abnormal Psychology. 2006;115(4):699-704. 